\title{
PEMBANGUNAN APLIKASI SEBAGAI MEDIA PEMBELAJARAN BANGUN RUANG TINGKAT SD/SMP DENGAN MENGGUNAKAN METODE MARKER AUGMENTED REALITY
}

\author{
Nur Alamsyah ${ }^{1}$, Rio Andriyat Krisdiawan ${ }^{2}$ \\ ${ }^{1}$ Fakultas Ilmu Komputer Universitas Nasional PASIM \\ Jalan Dakota No 8a. Kota Bandung Jawa Barat 40175 Telepon (022) 6072803 \\ ${ }^{2}$ Fakultas Ilmu Komputer Universitas Kuningan \\ Jl. Cut Nyak Dhien No.36A, Cijoho, Kec. Kuningan, Kabupaten Kuningan, Jawa Barat \\ 45513 \\ Email : ${ }^{1}$ nuralamsyah@pasim.ac.id / nuralamsyah.bdg@gmail.com, \\ 2rioandriyat@gmail.com / rioandriyat@uniku.ac.id
}

\begin{abstract}
Abstrak
Saat ini perkembangan teknologi mengalami kemajuan yang sangat pesat dan perkembangannya pun tidak dapat dihentikan. Dengan banyaknya teknologi canggih yang bermunculan, maka berbagai macam pekerjaan manusia dapat dikerjakan dengan cara yang lebih inovatif. Salah satu contohnya adalah dalam bidang pendidikan. Sekarang ini, muncul berbagai macam media pembelajaran berbasis teknologi salah satunya yaitu media pembelajaran menggunakan teknologi Augmented Reality atau sering disingkat menjadi AR. Pembangunan Aplikasi Sebagai Media Pembelajaran Bangun Ruang Tingkat SD/SMP Dengan Menggunakan Metode Marker Augmented Reality merupakan salah satu bentuk pemanfaatan teknologi AR dalam bidang pendidikan khususnya sebagai media pembelajaran. Dengan dibuatnya media pembelajaran bangun ruang berbasis Augmented Reality ini, diharapkan peserta didik dapat memahami materi pembelajaran dengan mudah, serta minat belajar peserta didik dapat meningkat karena objek-objek bangun ruangnya di desain menarik, penuh warna, dan interaktif untuk menghindari rasa bosan. Berdasarkan hal tersebut, maka penelitian ini menjadi salah satu terobosan baru dalam dunia pendidikan yang memanfaatkan kemajuan teknologi serta membantu para pengajar menyediakan media pembelajaran yang lebih menarik. Sementara, hasil dari penelitian ini yaitu berupa aplikasi AR dan buku (modul) matematika bangun ruang.
\end{abstract}

Kata Kunci : Augmented Reality, Marker Augmented Reality, Media Pembelajaran, Bangun Ruang.

\section{Abstract}

Nowadays, the development of technology is growing so rapidly and the development can not be stopped. With a lot of advanced technology that popping up, various kinds of human work can be done in more innovative way. One of the example is in the field of education. Right now, there is a lot variety of learning media based technology, one of them is learning media using Augmented Reality technology or often shortened become AR. Application Development as Solid Shape Learning Media for Elementary School/Junior High School Level Using Marker Augmented Reality Method is one of utilization of the AR technology in the field of education, especially as learning media. By making solid shape learning media based Augemented Reality technology, students are expected to understand learning materials easily, and student's learning interest can increased because the solid shape objects are build in attractive design colorful, and interactive to avoid boredom. Based on it, then this research become one of the new breakthrough in education field that utilizing the advancement of technology and help the teacher provide more interesting learning media. Meanwhile, the result of this research 
is an AR application and a solid shape mathematic book (handbook).

Keywords : : Augmented Reality, Marker Augmented Reality, Learning Media, Solid Shape.

\section{PENDAHULUAN}

Teknologi kini menjadi salah satu bagian dari setiap aktivitas yang dikerjakan manusia. Pertumbuhannya yang sangat cepat dan tidak terbendung menjadikannya sebagai komponen yang tidak terpisahkan dalam berbagai aspek kehidupan saat ini. Dengan hadirnya teknologi dalam berbagai aspek kehidupan manusia, memberikan dampak pada waktu pengerjaan dan juga tenaga yang dibutuhkan untuk menyelesaikannya. Salah satu contoh dari perkembangan teknologi saat ini yaitu munculnya berbagai macam perangkat mobile atau smartphone yang semakin canggih.

Saat ini penggunaan perangkat mobile bukan hanya sekedar untuk berkirim pesan atau untuk bertelepon saja, melainkan fungsinya telah bertambah luas. Dengan satu perangkat mobile kita dapat mencari dan mendapatkan informasi, mengontrol dan mengendalikan penggunaan peralatan kantor atau rumah, mengelola berkas, media edukasi, membayar berbagai macam tagihan, sampai dengan mengelola kegiatan administrasi di suatu lembaga/organisasi.

Semakin luasnya fungsi perangkat mobile tersebut didukung pula dengan perkembangan Android yang kian hari semakin maju. Android adalah salah satu sistem operasi untuk perangkat mobile atau telepon berbasis Linux yang mencakup sistem operasi, middleware, dan aplikasi. Sifatnya yang open source menjadikan banyak pengembang atau developer berlomba-lomba membuat aplikasi berbasis Android. Selain itu, berdasarkan data Operating System Market Share Indonesia periode Desember 2018 - Desember 2019 yang diperoleh dari statcounter, sistem operasi
Android menempati posisi $51.24 \%$ sementara sistem operasi iOS berada di posisi $3.66 \%$, dengan demikian sistem operasi Android menjadi sistem operasi yang paling banyak digunakan oleh masyarakat Indonesia.

Sejalan dengan perkembangan teknologi yang semakin maju, maka bidang pendidikan pun saat ini kian berkembang dan mengalami perubahan yang sangat signifikan, salah satu contohnya yaitu adanya alat peraga yang memanfaatkan kemajuan teknologi untuk mata pelajaran tertentu. Alat peraga tersebut biasanya digunakan pada mata pelajaran yang membutuhkan objek nyata dalam proses pembelajarannya yang bertujuan untuk membantu peserta didik dalam memahami materi pembelajaran.

Bangun ruang adalah salah satu materi dalam mata pelajaran matematika yang membutuhkan alat peraga dalam proses pembelajarannya. Tanpa adanya alat peraga langsung, peserta didik hanya dapat melihat gambar dua dimensi nya saja melalui buku atau mengimajinasikan sendiri objek bangun ruang tersebut. Selain itu, tanpa adanya alat peraga tingkat minat belajar peserta didik pun menjadi kurang karena peserta didik tidak dapat melihat maupun merasakan objek bangun ruang secara nyata. Dengan demikian, dibutuhkan alat peraga dalam rangka membantu peserta didik untuk mempelajari juga memvisualisasikan bangun ruang. Namun, alat peraga yang ada saat ini di pasaran harganya terbilang cukup mahal, dapat rusak maupun hilang, peserta didik tidak dapat membawa pulang alat peraga tersebut, dan sudah tidak sesuai lagi dengan kondisi saat ini yang serba menggunakan teknologi. Untuk menggantikan alat peraga konvensional tersebut, sekarang ini ada sebuah teknologi bernama Augmented Reality atau biasa 
JURNAL NUANSA INFORMATIKA

Volume 15 Nomor 1, Januari 2021

disingkat dengan AR.

Berdasarkan latar belakang

masalah yang telah diuraikan diatas, dapat diidentifikasikan masalah-masalah seperti berikut :

1. Bagaimana cara membuat aplikasi AR bangun ruang yang dapat memudahkan peserta didik untuk memahami materi pembelajaran.

2. Bagaimana cara membuat aplikasi AR bangun ruang yang dapat meningkatkan minat belajar peserta didik.

3. Bagaimana cara membuat aplikasi AR bangun ruang yang terdapat fitur kuis di dalamnya.

\section{METODE PENELITIAN}

Pada peneltian ini metode pelaksanaanya dilakukan melalui studi pendahuluan yaitu obeservasi lapangan, dilanjutkan dengan menentukan kriteria dan pembobotan sebagai langkah proses analisis dan dilanjutkan dengan Design dan Pengembangan Sistem.

\subsection{Metode pengumpulan data}

Untuk mendapatkan data-data dan informasi yang berkaitan dengan penelitian ini metode pengumpulan data yang digunakannya adalah sebagai berikut:

\section{Studi Pustaka}

Studi pustaka merupakan metode pengumpulan data dengan cara mencari teori-teori, artikel, karya ilmiah, buku-buku, media cetak, maupun sumber-sumber pustaka lainnya yang berhubungan dengan aplikasi yang akan dibangun.

\section{Observasi}

Pengumpulan data dengan cara melakukan pengamatan langsung terhadap sistem yang sedang berjalan.

3. Wawancara
p-ISSN : 1858-3911, e-ISSN : 2614-5405

https://journal.uniku.ac.id/index.php/ilkom

Melakukan pengumpulan data dengan cara melakukan tanya jawab dengan pihak-pihak terkait untuk mengetahui kebutuhan apa saja yang diperlukan.

\subsection{Model proses}

Model proses yang digunakan untuk membangun aplikasi AR bangun ruang ini

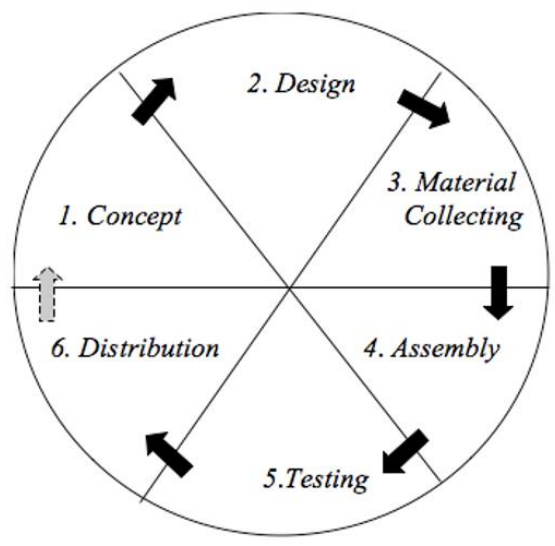

menggunakan metodologi pengembangan multimedia. Menurut Binanto (2010), metodologi pengembangan multimedia terdiri dari enam tahap yaitu concept (pengonsepan), design (perancangan), material collecting (pengumpulan bahan), assembly (penyusunan), testing (pengujian), dan distribution (pendistribusian). Alasan penggunaan metodologi pengembangan multimedia sebagai model proses dalam pembangunan aplikasi ini karena aplikasi yang dibangun termasuk ke dalam aplikasi multimedia, dimana terdapat proses pembuatan model 3D dan juga pemberian animasi kepada objek-objek 3D yang dibuat

\section{Gambar 1.1 Metodologi Pengembangan Multimedia (Luther, 1994)}

Adapun penjelasan dari metodologi pengembangan multimedia adalah sebagai berikut:

a) Concept (Pengonsepan)

Tahap concept (pengonsepan) adalah tahap untuk menentukan tujuan dan mengidentifikasi siapa pengguna aplikasi 
JURNAL NUANSA INFORMATIKA

Volume 15 Nomor 1, Januari 2021
p-ISSN : 1858-3911, e-ISSN : 2614-5405

https://journal.uniku.ac.id/index.php/ilkom (identifikasi user). Tujuan dan pengguna aplikasi perlu dipertimbangkan karena akan dapat mempengaruhi desain aplikasi dan juga model 3D yang dibuat. Selain itu, pada tahap ini juga akan menentukan jenis aplikasi (presentasi, interaktif, dan lainlain) dan tujuan dari aplikasi (hiburan, pelatihan, pembelajaran, dan lain-lain).

b) Design (Perancangan)

Pada tahapan ini, spesifikasi mengenai arsitektur program, gaya, tampilan, dan kebutuhan material/bahan untuk aplikasi dibuat. Spesifikasi dibuat serinci mungkin sehingga pada tahap berikutnya pengambilan keputusan baru tidak diperlukan lagi, cukup menggunakan keputusan yang sudah ditentukan pada tahap ini.

c) Material Collecting (Pengumpulan Bahan)

Material collecting adalah tahap pengumpulan atau pembuatan bahanbahan yang dibutuhkan untuk membangun multimedia seperti model $3 \mathrm{D}$, gambar clip art, foto, video, animasi dan lain-lain yang dapat diperoleh secara gratis maupun dengan memesan kepada pihak lain. Tahap ini dapat dikerjakan secara paralel (berbarengan) dengan tahap assembly atau dikerjakan secara linear (berurutan).

d) Assembly (Penyusunan)

Tahap assembly adalah tahap pembuatan aplikasi AR bangun ruang dengan menggabungkan semua material yang telah dikumpulkan pada tahap sebelumnya.

e) Testing (Pengujian)

Pada tahap testing (pengujian) dilakukan pengujian terhadap aplikasi multimedia yang telah dibuat dengan cara menjalankan aplikasinya dan melihat apakah terdapat kesalahan (error) atau tidak. Testing pada aplikasi dilakukan sebanyak dua tahap, yaitu alpha testing dan beta testing. Alpha testing adalah pengujian yang dilakukan oleh pembuat atau developer nya, sementara beta testing adalah pengujian yang dilakukan oleh pengguna akhir atau end user.

f) Distribution (Pendistribusian)

Pada tahap ini, aplikasi yang telah dibuat akan disimpan ke dalam suatu media penyimpanan untuk di distribusikan ke pengguna akhir atau end user. Tahap ini juga dapat disebut tahap evaluasi untuk pengembangan aplikasi yang sudah jadi supaya menjadi lebih baik. Hasil evaluasi dapat digunakan sebagai masukkan untuk tahap concept pada aplikasi selanjutnya.

\subsection{Metode pembangunan sistem}

Metode pendekatan pembangunan sistem dalam pengembangan aplikasi ini menggunakan Object Oriented. Adapun alasan menggunakan metode ini dikarenakan pengembangan sistem nya menggunakan bahasa pemrograman berbasis Object Oriented, dimana dengan menggunakan pendekatan tersebut akan memudahkan dalam proses pemodelan nya. Adapun hasil analisis nya digambarkan dengan menggunakan alat bantu Unified Modeling Language (UML). UML merupakan alat bantu yang digunakan untuk mempermudah pengembangan aplikasi berbasis Object Oriented dimana pemodelan UML mendeskripsikan secara lengkap bagaimana aplikasi akan digunakan oleh penggunanya. Diagram-diagram yang akan digunakan dalam analisis sistem yang dibangun adalah sebagai berikut:

a) Use Case diagram

b) Class diagram

c) Sequence diagram

d) Activity diagram

\section{HASIL DAN PEMBAHASAN}

3.1 Perancangan Aplikasi

3.1.1 Use Case Diagram 
JURNAL NUANSA INFORMATIKA

Volume 15 Nomor 1, Januari 2021
p-ISSN : 1858-3911, e-ISSN : 2614-5405

https://journal.uniku.ac.id/index.php/ilkom
Use case atau diagram use case
merupakan pemodelan untuk menggambarkan kelakuan (behavior) dari aplikasi yang akan dibangun. Use case mendeskripsikan sebuah interaksi antara satu atau lebih aktor dengan aplikasi yang dibangun. Atau dengan kata lain, use case digunakan untuk mengetahui fungsi apa saja yang ada di dalam sebuah aplikasi dan siapa saja yang berhak menggunakan fungsi-fungsi itu. Pendefinisian ini meliputi identifikasi user, identifikasi use case dan skenario atau cara kerja dari aplikasi yang dibangun.

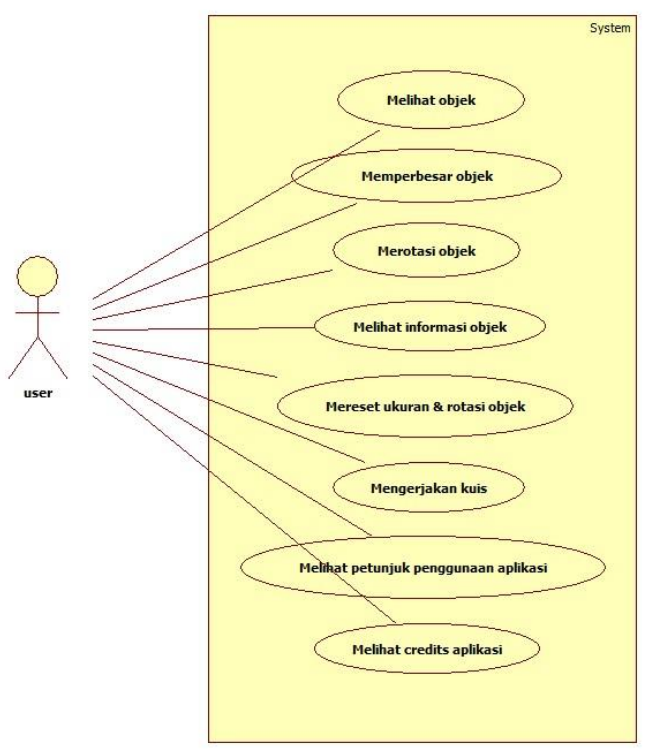

Gambar 3.1 Use Case Diagram Aplikasi AR Bangun Ruang

\subsubsection{Activity Diagram}

Diagram aktivitas atau activity diagram menggambarkan workflow (aliran kerja) atau aktivitas yang terjadi pada sebuah sistem. Dari pertama hingga akhir, diagram ini menunjukkan langkah-langkah dalam proses kerja sistem yang telah dibuat.

a. Activity Diagram - Melihat Objek

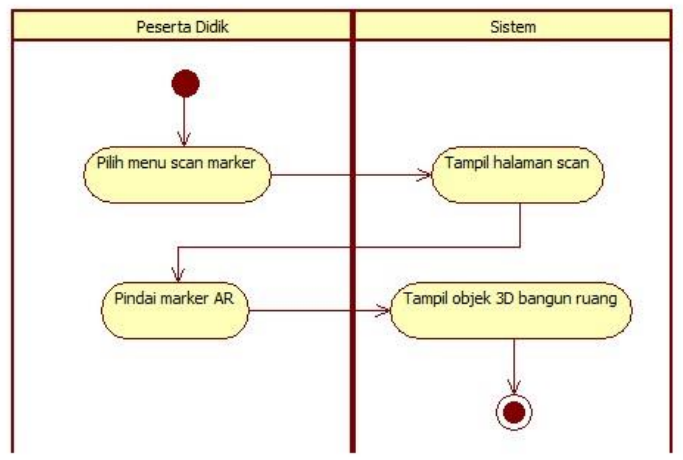

Gambar 3.2 Activity Diagram Melihat Objek

b. Activity Diagram - Melihat Informasi Objek

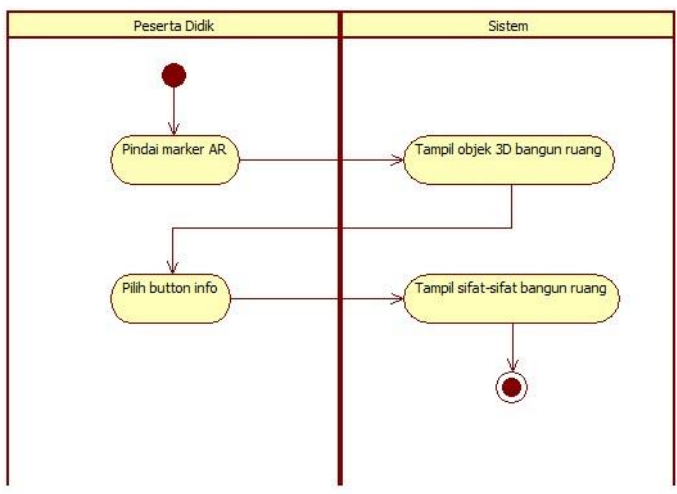

Gambar 3.3 Activity Diagram Melihat Informasi Objek

c. Activity Diagram - Mengerjakan Kuis

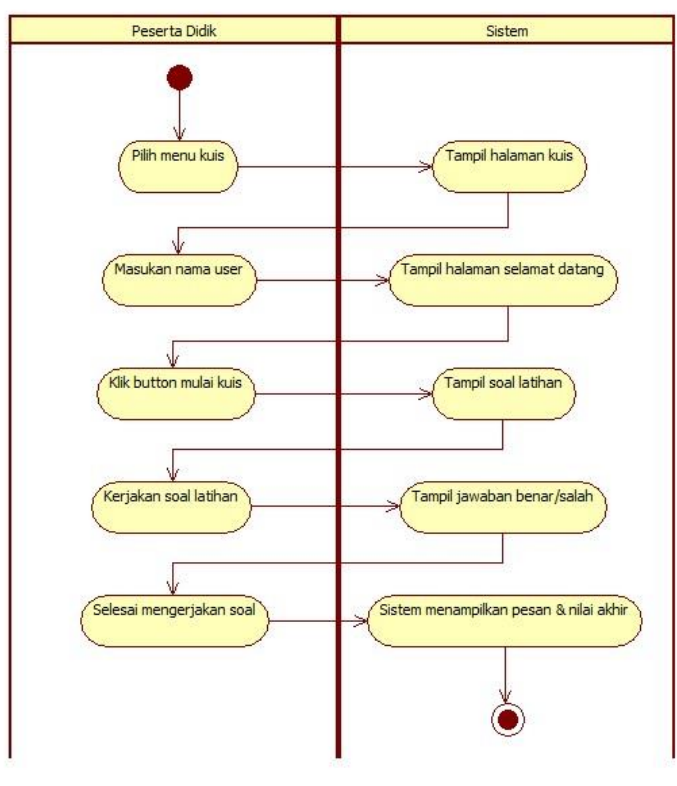


JURNAL NUANSA INFORMATIKA

Volume 15 Nomor 1, Januari 2021

Gambar 3.4 Activity Diagram Mengerjakan Kuis

d. Activity Diagram - Melihat Petunjuk Penggunaan Aplikasi

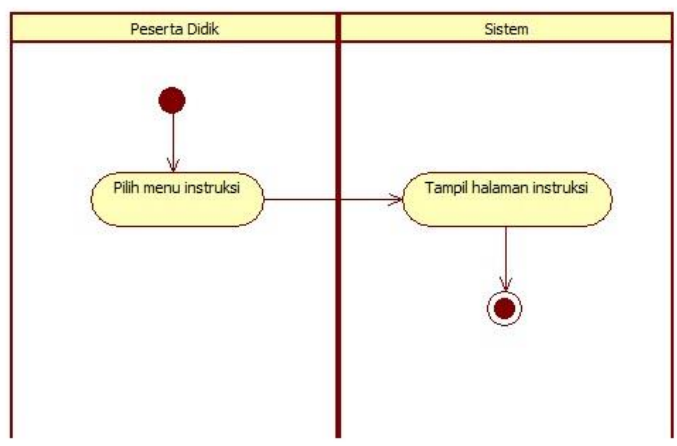

Gambar 3.5 Activity Diagram Melihat Petunjuk Penggunaan Aplikasi

\subsubsection{Sequence Diagram}

Diagram sekuen atau sequence diagram merupakan diagram yang menggambarkan kelakuan objek pada use case secara berurutan dengan mendeskripsikan life time (waktu hidup) objek dan pesan yang dikirimkan dan diterima antar objek.

\section{a. Sequence Diagram - Melihat Objek}

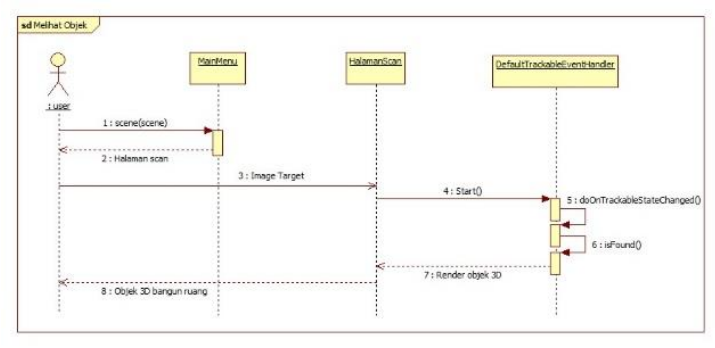

Gambar 3.6 Sequence Diagram Melihat Objek

\section{b. Sequence Diagram - Melihat Informasi Objek}

p-ISSN : 1858-3911, e-ISSN : 2614-5405

https://journal.uniku.ac.id/index.php/ilkom

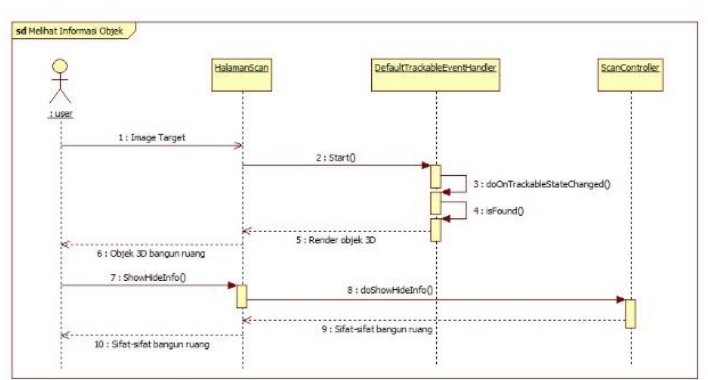

Gambar 3.7 Sequence Diagram Melihat Informasi Objek

c. Sequence-Mengerjakan Kuis

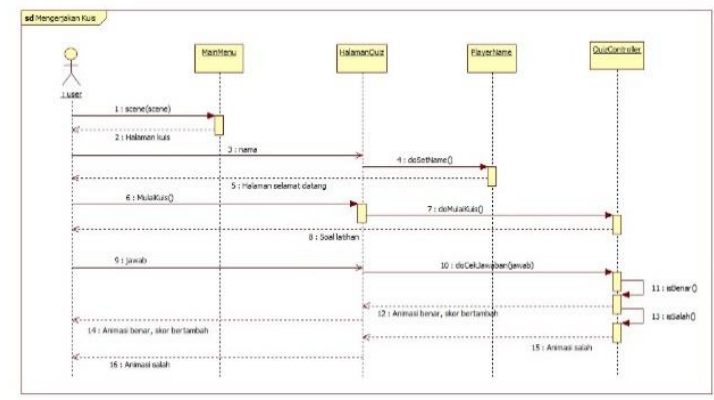

Gambar 3.8 Sequence Diagram

Mengerjakan Kuis

\subsubsection{Class Diagram}

Diagram kelas atau class diagram merupakan diagram yang menggambarkan struktur sistem dari segi pendefinisian kelaskelas yang akan dibuat untuk membangun sistem. Kelas memiliki apa yang disebut atribut dan metode atau operasi. Di bawah ini class diagram dari aplikasi AR bangun ruang:

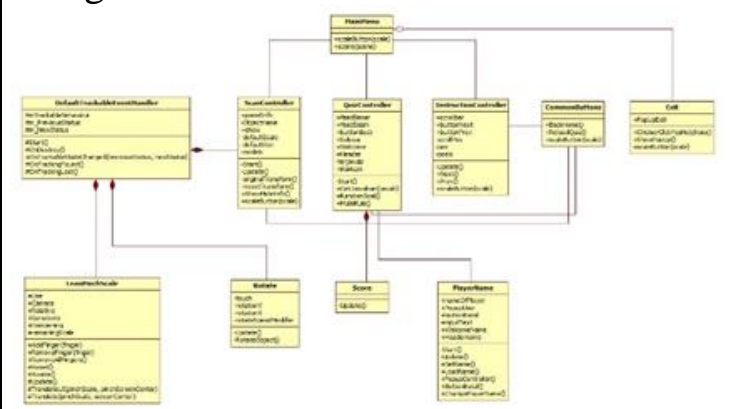

Gambar 3.9 Class Diagram Aplikasi AR Bangun Ruang 
JURNAL NUANSA INFORMATIKA

Volume 15 Nomor 1, Januari 2021

\subsection{Hasil}

1. Tampilan Menu Utama

Saat user pertama kali membuka aplikasi AR bangun ruang, pertama-tama aplikasi akan menampilkan splash screen bawaan Unity. Setelah splash screen ditampilkan, aplikasi akan menampilkan menu utama.

Pada menu utama, terdapat 5 button dimana 4 di antaranya merupakan button yang menuju 4 scene yang berbeda. Sementara 1 button lainnya, yaitu button keluar akan menampilkan sebuah popup window. Selain itu, pada menu utama terdapat animasi dan juga backsound agar aplikasi semakin menarik untuk user. Berikut merupakan tampilan dari menu utama aplikasi AR bangun ruang:

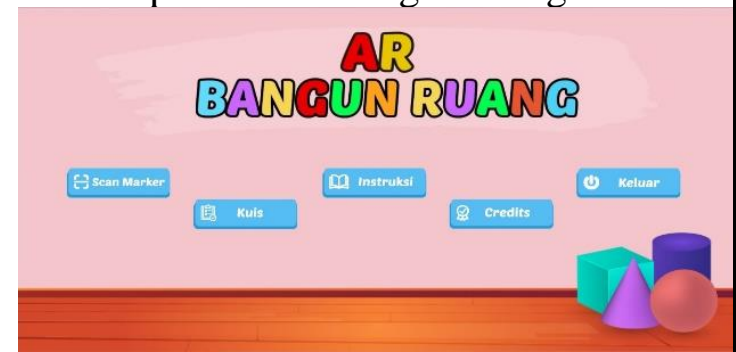

Gambar 3.10 Tampilan menu utama

2. Tampilan Halaman Scan Marker

Selanjutnya adalah tampilan halaman scan marker. Halaman scan marker ini akan ditampilkan ketika user menekan button scan marker yang ada di halaman utama. Ketika halaman scan marker terbuka, maka secara otomatis kamera akan aktif. Scene ini digunakan untuk mendeteksi sebuah marker yang telah ditentukan. Berikut merupakan tampilan dari halaman scan marker:

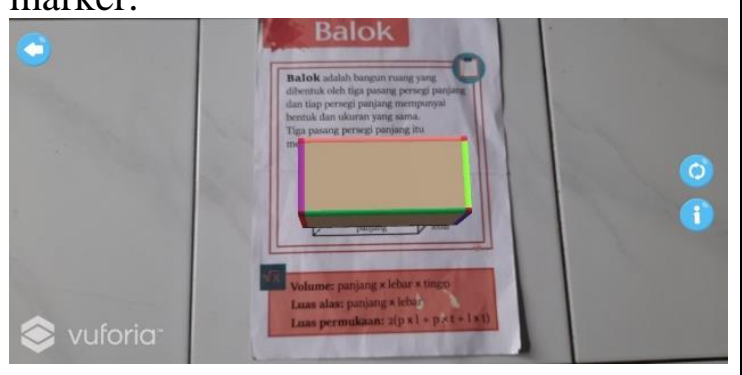

Gambar 3.11 Halaman scan marker
p-ISSN : 1858-3911, e-ISSN : 2614-5405

https://journal.uniku.ac.id/index.php/ilkom

\section{Tampilan Halaman Kuis}

Halaman kuis merupakan halaman yang digunakan sebagai sarana untuk mengevaluasi hasil belajar peserta didik. Di halaman kuis ini terdapat 10 soal mengenai bangun ruang yang berbentuk pilihan ganda, setiap peserta didik yang menjawab pertanyaan dengan benar maka nilai skor akan bertambah 10 sedangkan ketika salah, skor tidak akan bertambah. Berikut tampilan dari halaman kuis:

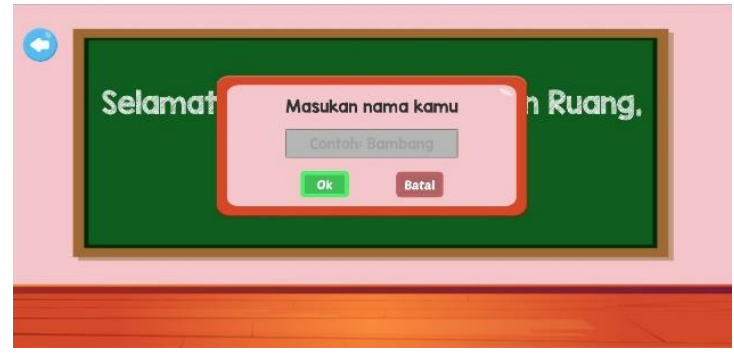

Gambar 3.12 Halaman Kuis

4. Contoh soal kuis

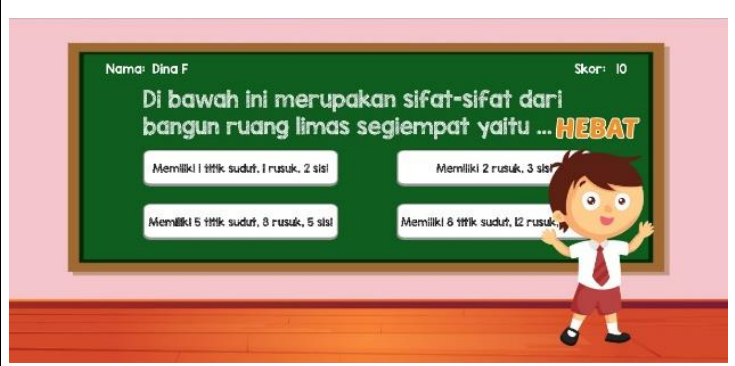

Gambar 3.13 Contoh soal kuis

5. Tampilan soal kuis selesai dikerjakan

Setelah peserta didik menyelesaikan seluruh pertanyaan, maka aplikasi akan menampilkan skor akhir peserta didik dan tulisan bahwa seluruh pertanyaan telah diselesaikan. Berikut merupakan tampilan ketika peserta didik telah menyelesaikan seluruh pertanyaan:

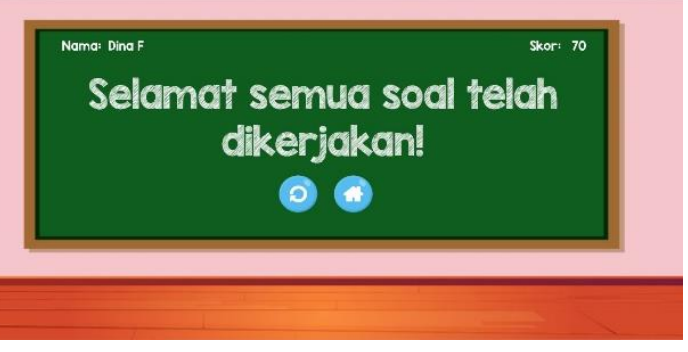


JURNAL NUANSA INFORMATIKA

Volume 15 Nomor 1, Januari 2021

\section{Gambar 3.14 Tampilan kuis selesai dikerjakan}

\section{Tampilan Halaman Instruksi}

Halaman instruksi merupakan halaman yang berfungsi sebagai petunjuk untuk menggunakan fitur-fitur yang terdapat di halaman scan marker. Berikut merupakan tampilan halaman instruksi:

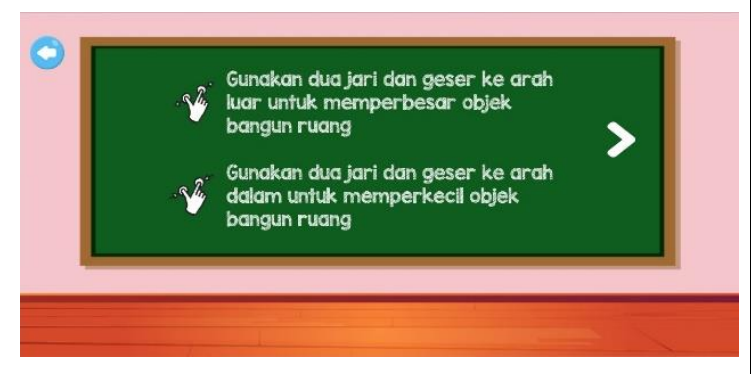

Gambar 3. 15 Tampilan Menu Halaman Instruksi

\section{KESIMPULAN}

1. Berdasarkan penelitian yang telah dilakukan, maka diperoleh kesimpulan sebagai berikut:

2. Aplikasi yang dibangun memudahkan peserta didik dalam memahami materi pembelajaran bangun ruang.

3. Aplikasi AR bangun ruang dapat meningkatkan minat belajar peserta didik.

4. Aplikasi AR bangun ruang telah dilengkapi dengan fitur kuis yang dapat digunakan sebagai sarana tolak ukur untuk mengetahui tingkat pemahaman peserta didik terhadap materi pembelajaran.

\section{SARAN}

Adapun saran untuk penelitian selanjutnya adalah pengembangan aplikasi AR bangun ruang yang jauh lebih baik lagi. Pengembangan dapat dilakukan pada beberapa bagian sebagai berikut:

1. Penambahan materi dan animasi yang masih berkaitan dengan bangun ruang seperti materi mengenai jaring-jaring.
p-ISSN : 1858-3911, e-ISSN : 2614-5405

https://journal.uniku.ac.id/index.php/ilkom

2. Pengembangan pada desain aplikasi dan model 3D.

3. Perbaikan fitur reset pada halaman scan marker.

4. Penambahan soal latihan di halaman kuis.

\section{DAFTAR PUSTAKA}

[1] A.S. Rosa, dan Shalahuddin M. 2015. Rekayasa Perangkat Lunak Terstruktur dan Berorientasi Objek. Bandung: Informatika Bandung.

[2] Al Fatta, Hanif. 2007. Analisis dan Perancangan Sistem Informasi Untuk Keunggulan Bersaing Perusahaan dan Organisasi Modern. Yogyakarta: Penerbit Andi.

[3] Andriyadi, Anggi. 2018. Augmented Reality With AR Toolkit Reality Leaves a lot To Imagine. Surabaya: CV Garuda Mas Sejahtera.

[4] Arifitama, Budi. 2017. Panduan Mudah Membuat Augmented Reality. Yogyakarta: Penerbit ANDI.

[5] Arsyad, Azhar. 2011. Media Pembelajaran. Jakarta: Rajawali Pers.

[6] Binanto, Iwan. 2010. Multimedia Digital - Dasar Teori dan Pengembangannya. Yogyakarta: Andi.

[7] Borko, Furht. 2011. Handbook of Augmented Reality. New York: Springer.

[8] Budiyono, dkk. 2016. Geometri dan Pengukuran. Yogyakarta: Penerbit Ombak.

[9] Chari, dkk. 2008. Augmented Reality Using Over Segmentation: Center for Visual Information Technology. 
JURNAL NUANSA INFORMATIKA

Volume 15 Nomor 1, Januari 2021

International Institute of Information Technology.

[10] Craig, Alan B. 2013. Understanding Augmented Reality: Concepts and Application. USA: Newnes. Andi.

[11] Djuwita, Dwi. 2015. Bangun Datar dan Bangun Ruang. Bandung: PT Remaja Rosdakarya.

[12] Dris, J., dan Tasari. 2011. Matematika Jilid 2 Untuk SMP dan MTS Kelas VIII. Jakarta: Pusat Kurikulum dan Perbukuan, Kementrian Pendidikan Nasional.

[13] Elcom. 2013. Belajar Kilat: Hebat Mengedit Dengan Adobe Photoshop CS6. Yogyakarta: Penerbit ANDI.

[14] Enterprise, Jubilee. 2016. Blender untuk Pemula. Jakarta: PT Elex Media Komputindo.

[15] Goenarso, Arief, dan Josias D. Tantotos. 2014. Pintar Matematika Bangun Ruang. Jakarta: Lestari Kiranatama.

[16] Jogiyanto, H. M, 1999. Analisis dan Desain Sistem Informasi. Yogyakarta: Andi.

[17]Komputer,Wahana. 2014. Mudah Membuat Game 3 Dimensi Menggunakan Unity 3D. Semarang: Penerbit ANDI.

[18] Mashuri, Sufri. 2019. Media Pembelajaran Matematika.Yogyakarta: Deepublish.

[19] Meilani, Gina Rahayu. 2018. Membangun Aplikasi Augmented Reality Dengan Unity. Surabaya: CV Garuda Mas Sejahtera.
p-ISSN : 1858-3911, e-ISSN : 2614-5405

https://journal.uniku.ac.id/index.php/ilkom

[20] Pamoedji, Andre Kurniawan, Maryuni, dan Ridwan Sanjaya. 2017. Mudah Membuat Game Augmented Reality (AR) dan Virtual Reality (VR) dengan Unity 3D. Jakarta: PT Elex Media Komputindo.

[21] Patkar, Raviraj S., S. Pratap Singh, dan Swati V. Birje. 2013. Marker Based Augmented Reality Using Android OS. India: International Journal of Advanced Research in Computer Science and Software Engineering. Vol. 3, No. 5:6469.

[22] Raymond McLeod, Jr. dan George P. Schell. 2007. Management Information Systems. New Jersey: PEARSON Education.

[23] Safaat, Nazruddin. 2012. Pemrograman Aplikasi Mobile Smartphone dan Tablet PC Berbasis Android. Bandung: Informatika Bandung.

[24] Zaki, Ali. Edy Winarno, dan SmitDev Community. 2016. Animasi Karakter dengan Blender dan Unity. Jakarta: PT Elex Media Komputindo.

[22] Raymond McLeod, Jr. dan George P. Schell. 2007. Management Information Systems. New Jersey: PEARSON Education. 